\title{
Role of Mycorrhiza as Biofertilization of Banana Grand Naine on Nursery Stage
}

\author{
H.A. Emara ${ }^{1 *}$, A. Nower ${ }^{1}$, E. Hmza ${ }^{1}$, M. Saad ${ }^{2}$ and F. El Shaib ${ }^{2}$ \\ ${ }^{1}$ Plant Biotechnology Department, Genetic Engineering and biotechnology Research Institute, \\ University of Sadat City, Egypt \\ ${ }^{2}$ Tropical fruit Department, Horticultural Research Institute, Agricultural Research Center, \\ Ministry of Agriculture and reclamation Land, Egypt \\ *Corresponding author
}

\section{Keywords}

Banana, Biofertilizer, Mycorrhiza, Nursery, N-

P-K, Growth parameters, Root parameters

Article Info

Accepted: 06 September 2018 Available Online: 10 October 2018

\section{A B S T R A C T}

The effect of arbuscular mycorrhizal fungi (AMF) on growth and nutrient uptake of banana plants (Musa acuminate) cv. 'Grande Naine' during nursery stage in a greenhouse was tested. After acclimatization stage, plants were inoculated with various doses of Arbuscular mycorrhiza fungi (AMF). AMF inoculum consisted of a mixture of Glomus etunicatum, Glomus intraradices and Glomus monosporum spores at concentration of 250 spore/ml. After 20 weeks, vegetative growth parameters, root parameters, mineral content and protein were determined. Vegetative growth of infected plants was superior compared with control (non-inoculation). On the other side, mycorrhiza inoculation resulted in positive effect on banana root parameters; number, tall and weight of roots, all inoculation treatments gave higher root parameters than the control (without addition of mycorrhiza). Also, mineral up take, and total protein of banana plants were enhanced as a result of inoculation; especially $\mathrm{N}, \mathrm{P}$ and $\mathrm{K}$ as well as protein. These results may be due to the symbiotic effect of AMF, where it saves a good soil environment around the root zone of plant and the later supply mycorrhiza with its hormones requirements. Also, mycorrhiza help plants to improve nutrients uptake by direct or indirect ways.

\section{Introduction}

Micropropagation techniques increase the scale, speed of production and yield of healthier plants for fruit tree propagation. However, several problems limit the widespread use of micropropagation, the most limitation reason is transplanting of in vitro plantlets to ex vitro conditions, it is the most critical. High rate of mortality is often observed upon transfer to ex vitro conditions because the cultured plants have functionally impaired stomata and poorly developed cuticle and root systems. Although some plant species acclimatize quickly due to faster root and shoot growth, others do not lead to an extended weaning stage, often accompanied by high losses and a large increase in use of fertilizer, pesticides and other residual chemicals (Gaur and Adholeya, 1999). The major problem of commercial micropropagated plant production is low 
survival and poor growth while shifting these plantlets to field conditions. Plant loss is associated with the fact that micro-propagated plants have functionally less rhizosphere microorganisms such as mycorrhizae. Plant production through biofertilizer technique can benefit through the utilization of mycorrhizae. Improved performance of endomycorrhizal plants is usually due to enhanced uptake of nutrients, especially phosphorous (Monticelli et al., 2000). Rai (2001) indicated that AMF improves bio-priming of micro propagated plantlets and plays a significant role in ensuring the health of plantlets. Mycorrhiza can act as bio-regulators, bio-fertilizers and bioprotectors, making possible the production of healthy, high-quality plants with low chemical inputs (Lovato et al., 1996).

It has been reported that inoculation of arbuscular mycorrhizal AMF to the roots of micro propagated plantlets plays a beneficial role in their post-transplanting performance (Kapoor et al., 2008). Salamanca et al., (1992) demonstrated that AMF reduced the length of the micro propagated plant production cycle from 18 to 10 weeks. Fortuna et al., (1996) conclude that AMF can be used as a biotechnological tool to overcome blocked apical growth and to reduce chemical inputs, especially phosphor, to micro propagated fruit trees. Mycorrhiza can also improve transplant viability (Biermann and Linderman, 1983). Mycorrhizae form symbiotic associations between plant roots and certain soil fungi which play a key role in nutrient cycling in the ecosystem and also protect plants against environmental and cultural stress (Ortas and Varma, 2007 and Ortas, 2008). Most of the major plant families are able to form mycorrhizal associations, the AMF association being the most common mycorrhizal type involved in agricultural systems (AzcónAguilar and Barea, 1997; Ortas, 2008). Many studies on plants such as cherimoya (AzconAguilar et al., 1996; Padilla and Encina,
2005), walnut (DolcetSanjuan et al., 1996), chestnut (Martins et al., 1997), banana (YanoMelo et al., 1999, Romero et al., 2005 and Gaidashova et al., 2013), red raspberry (Taylor and Harrier 2000), strawberry (Taylor and Harrier 2001), pepper (Estrada-Luna and Davies 2003), Ficus benjamina (Srinath et al., 2003), grape (Krishna et al., 2005) and cherry (Aka-kacar et al., 2010) have utilized AMF to increase the growth rate and reduce mortality of plantlets during acclimatization. The present work was conducted to determine the role of mycorrhiza in improvement plant growth parameters, rooting and nutrient uptake of banana after acclimatization stage in nursery.

\section{Materials and Methods}

\section{Biological material}

\section{Plant materials}

Micropropagated banana (Musa acuminate) cultivar Grande Naine was resulted from in vitro rooting stage (as described by Emara et al., 2018) was removed washed well to remove the medium and obtain clean roots. To avoid fungal and insects attack when plantlets were transplanted to ex vitro conditions, plantlets were rinsed in antifungal solution. Plantlets, approximately $8 \pm 1 \mathrm{~cm}$ in height with three fully developed leaves, were transplanted to 24-L trays (20 plantlets/tray), that filled with a mixture of peat moss and perlite $(1: 1, \mathrm{v} / \mathrm{v})$.

\section{Acclimatization conditions}

Then, they were transferred to greenhouse (9 $\mathrm{m}$ in width $\times 60 \mathrm{~m}$ in length) covered with black mesh shade was $63 \%$, temperature was about $30 \pm 5{ }^{\circ} \mathrm{C}$ and relative humidity was 70 $80 \%$, Finally, plantlets incubated under tunnel ( $1 \mathrm{~m}$ in width and $45 \mathrm{~m}$ in length). The tunnel was covered with transparent polyethylene 
sheets to raise the relative humidity around the plantlets and the ground of tunnel was covered with black polyethylene sheets to avoid growing of grass. As a type of hardening, the transparent plastic sheets have been gradually removed during the day and returned at night, the sheet was totally removed after 3 weeks from transplanting.

\section{Nutrition treatments}

Plantlets fertilization began in the second week of culture, plantlets were fertilized by commercial nutrient solution (kristalon $0.5 \mathrm{~g} / \mathrm{l}$ ) contained NPK in a percent of 19:19:19 (using manual sprayer $20 \mathrm{~L}$ capacity) daily with nutrient solution containing commercial. Sprinkler mist system was applied to save relative humidity around plantlets. Acclimatization process was achieved after 6 weeks from culturing and acclimatized plantlets became ready to be transplanted individually into black polyethylene plastic leaky bags of $25 \mathrm{~cm}$ width and $25 \mathrm{~cm}$ length, filled with soil mixture of sand and rice shell $(2: 1, \mathrm{v} / \mathrm{v})$. Where drip irrigation system was implemented. Plants were fertilized for four days/week with commercial nutrient solution containing commercial fertilizer of NPK (kristalon $0.5 \mathrm{~g} / \mathrm{l}$ ). When plantlets transplanted to black polyethylene plastic leaky bags $(25 \mathrm{~cm})$, kristalon was alternated with Agromore $0.5 \mathrm{~g} / \mathrm{l}$, which contained NPK at the ratio of 13: $4: 42+1 \mathrm{Mg}$. Chelated microelements, i.e., Fe (0.5 g/l), Zn (0.25 g/l) and $\mathrm{Mn}(0.25 \mathrm{~g} / \mathrm{l})$ were applied once a week.

\section{Mycorrhiza inoculum}

Arbuscular mycorrhiza fungi (AMF) inoculum was obtained from Microbial Inoculum Activity facility, Faculty of Agriculture, Ain Shams University. AMF inoculum consisted of a mixture of Glomus etunicatum, Glomus intraradices and Glomus monosporum spores at concentration of $250 \mathrm{spore} / \mathrm{ml}$.

\section{Inoculation process and experimental} design

Arbuscular mycorrhiza fungi (AMF) were applied by mixing with irrigation water immediately after 15 days of planting on black polyethylene plastic leaky bags at five treatments [uninoculated (control), 250, 500, 750 and 1000spore/pot].

An experiment with 5 treatments lasting 140 days was established. Ten replicates were considered per treatment (50 plants) and plants were disposed in the greenhouse in a completely randomized design.

During this period, plants were grown under greenhouse conditions with an ambient temperature of $27-32{ }^{\circ} \mathrm{C}$ and a relative humidity of $70-80 \%$ and were irrigated with water according to water requirements. Plants were fertilized according to the commercial standard fertilizer programs.

\section{Data assessment procedures}

\section{Plant morphology}

Plants were evaluated after 20 weeks from the planting date.

The data which recorded on plant growth were number of functional leaves, plant height $(\mathrm{cm})$, shoot length $(\mathrm{cm})$, pseudostem diameter $(\mathrm{cm})$ and leaf area $\left(\mathrm{cm}^{2}\right)$. While the biomass data were fresh and dry shoot weight $(\mathrm{g})$ and fresh root weight $(\mathrm{g})$. Also, root characteristics were estimated as root number and length of primary roots $(\mathrm{cm})$.

\section{Nutrient elements analysis}

\section{Prepared samples}

Macroelements i.e., nitrogen, phosphorus and potassium, were determined in the areal part 
of the plants. So, the pseudostem and leaves of the banana plants were washed in mild detergent, rinsed three times in distilled water, avoiding aging or necrotic tissue, and prepared for foliar analysis.

Samples were then dehydrated in a temperature-controlled fan-ventilated oven at $40{ }^{\circ} \mathrm{C}$ for 48 hours, ground in a ball mill and digested in wet acid (Jones et al., 1991), using nitric and perchloric acid.

Analysis for all elements except nitrogen was carried out with emission spectrometer. Readings results were done Twice for each sample (Jackson, 1958). Nitrogen content was determined according to the Kjeldahl procedure (Rund, 1984).

\section{Mycorrhizal infection assessment}

To assess mycorrhizal infection, a small root sample; $5 \%$ of fresh weight of the whole root system, was used to estimate the percentage of arbuscular mycorrhizal fungi (AMF\%) which infected roots.

Samples were stained with $0.05 \%$ trypan blue in lactic acid (Phillips and Hayman, 1970) modified by the procedure described by (Koske and Gemma. 1989). The percentage of roots colonization was determined on twenty sections $(1-\mathrm{cm})$ of stained root, fixed on slides and examined with a light microscope as described by (Brundett et al., 1985).

\section{Statistical analysis}

All experiments were arranged in completely randomized design SAS Institute (2002).

Differences among the various treatments were compared using LSD test at 5\% according to according to Steel and Torrie (1980). M-state free computer program was used for analysis.

\section{Results and Discussion}

\section{Effect of arbuscular mycorrhizal fungi (AMF) on plant growth development}

Application of inoculation of mycorrhiza induced benefits in terms of banana plantlet development and nutrient uptake. However, plants treated with mycorrhiza showed higher significant increasing of growth parameters. Registed values for all growth parameters were significantly enhanced for mycorrhiza inoculation as compared with non-inoculation treatments in all different concentrations of Mycorrhiza (Table 1 and Figure 1).

All mycorrhiza inoculation treatments (250, 500,750 or 1000 spores/pot) resulted in a significant maximized number of leaves (13.7, 10.7, 9.7 and 11.7 leaves/ plant, respectively) compared with non-inoculation plants (8.7 leaves/plant).

Number of leaves possessed increasing percent as compared with non-inoculation ranged from 16.9 to $65.1 \%$ compared with non-inoculated plants (as shown in Table 1 and Figure 1). Regarding the effect of AMF on leaf area, all inoculation plants positively affected leaf area, anyway, the percent of enhancement in leaf area compared with control ranged from 8.70 to $29.78 \%$.

The same effect has been observed in all growth parameters, i.e.; plant height, pseudostem length and diameter, plant fresh weight and plant dry weight. Where, the values registered for all growth parameters are high as compared with the control.

The priority percent of AMF inoculation were ranged from 12.4 to $30.4 \%$ for plant height, 33.21 to $42.86 \%$ for pseudostem length, 38.10 to $71.43 \%$ for pseudostem diameter, 21.84 to $51.72 \%$ for fresh weight and 26.82 to $53.07 \%$ for dry weight 
Table.1 Effect of mycorrhiza inoculation (AMF) on growth parameters of Banana plantlet in nursery

\begin{tabular}{|c|c|c|c|c|c|c|c|}
\hline $\begin{array}{l}\text { Inoculation } \\
\text { (spores/pot) }\end{array}$ & $\begin{array}{c}\text { NO of leaves } \\
(\% *)\end{array}$ & $\begin{array}{c}\text { Leaf area } \\
\left(\mathrm{mm}^{2}\right)(\% *)\end{array}$ & $\begin{array}{c}\text { Plant } \\
\text { height }(\mathrm{cm}) \\
(\% *)\end{array}$ & $\begin{array}{l}\text { pseudostem } \\
\text { length }(\mathrm{cm}) \\
(\% *)\end{array}$ & $\begin{array}{l}\text { Pseudostem } \\
\text { diameter } \\
(\mathrm{cm})(\% *)\end{array}$ & $\begin{array}{l}\text { Fresh Weight } \\
\quad(\mathrm{g})(\% *)\end{array}$ & $\begin{array}{l}\text { Dray Weight } \\
\text { (g) }(\% *)\end{array}$ \\
\hline Control (0) & 8.3 & 460 & 70.3 & 28 & 2.1 & 261 & 17.9 \\
\hline T1(250) & $13.7(65.06)$ & 597 (29.78) & $91.7(30.44)$ & $40(42.86)$ & $3.6(71.43)$ & $396(51.72)$ & $27.4(53.07)$ \\
\hline $\mathrm{T} 2(500)$ & 10.7 (28.92) & $500(8.70)$ & $79(12.38)$ & 36.7 (3.07) & $3.0(42.86)$ & $318(21.84)$ & $22.7(26.82)$ \\
\hline T3(750) & $9.7(16.87)$ & $519(12.83)$ & $83(18.07)$ & $36.3(29.64)$ & $2.9(38.10)$ & 387 (48.28) & $26.4(47470)$ \\
\hline $\mathrm{T} 4(1000)$ & 11.7(40.96) & $544(18.26)$ & 85.7 (21.91) & $37.3(33.21)$ & $2.9(38.10)$ & $323(23.76)$ & $22.7(26.82)$ \\
\hline $\begin{array}{l}\text { LSD value } \\
\text { at } 5 \%\end{array}$ & 2.010 & 86.08 & 8.513 & 3.268 & 0.4360 & 45.75 & 3.045 \\
\hline
\end{tabular}

Where: $(\% *)$ is the percentage of increasing than control (non-inoculation plants)

Table.2 Effect of mycorrhiza inoculation (AMF) on the root system parameters of banana plantlets in nursery

\begin{tabular}{|c|l|l|l|}
\hline $\begin{array}{c}\text { Inoculation } \\
(\text { spores/pot) }\end{array}$ & \multicolumn{1}{|c|}{$\begin{array}{c}\text { NO of Roots } \\
(\% *)\end{array}$} & \multicolumn{1}{|c|}{$\begin{array}{c}\text { Root length }(\mathrm{cm}) \\
(\% *)\end{array}$} & $\begin{array}{c}\text { Root fresh weight }(\mathrm{g}) \\
(\% *)\end{array}$ \\
\hline Control $(\mathbf{0})$ & 17.3 & 22.3 & 99 \\
\hline T1(250) & $34.7(100.58)$ & $34.0(52.47)$ & $154(55.56)$ \\
\hline T2(500) & $27.3(57.80)$ & $30.0(34.53)$ & $92.7(6.36)$ \\
\hline T3(750) & $30(73.41)$ & $30.0(34.53)$ & $148(49.50)$ \\
\hline T4(1000) & $31.3(80.93)$ & $37.7(69.06)$ & $101(2.02)$ \\
\hline LSD value at 5\% & 3.803 & 4.589 & 29.09 \\
\hline
\end{tabular}

Where $(\% *)$ is the percentage of increasing than control (non-inoculation)

Table.3 Effect of mycorrhiza inoculation (AMF) on some macroelements content and protein \% of banana plantlets during nursery

\begin{tabular}{|c|c|c|c|c|}
\hline $\begin{array}{c}\text { Inoculation } \\
(\text { spores/pot) }\end{array}$ & N\% $(\% *)$ & P\% $(\% *)$ & K\% $(\% *)$ & $\begin{array}{c}\text { Protein } \% \\
(\% *)\end{array}$ \\
\hline Control (0) & 2.2 & 0.63 & 6.5 & 14 \\
\hline T1(250) & $3.6(63.6)$ & $0.83(31.75)$ & $11.0(69.2)$ & $22.7(62.14)$ \\
\hline T2(500) & $3.4(54.5)$ & $0.7(11.10)$ & $7.4(13.8)$ & $20.9(49.28)$ \\
\hline T3(750) & $3.3(50.0)$ & $0.77(22.20)$ & $8.7(33.8)$ & $20.6(47.14)$ \\
\hline T4(1000) & $3.5(59.0)$ & $0.7(11.10)$ & $9.2(41.5)$ & $22(57.140$ \\
\hline LSD value at 5\% & 0.1566 & 0.07832 & 0.1837 & 1.221 \\
\hline
\end{tabular}

Where: $(\% *)$ is the percentage of increasing than control (non-inoculation) 
Fig.1 Effect of mycorrhiza inoculation (AMF) on growth parameters of Banana plantlet in nursery

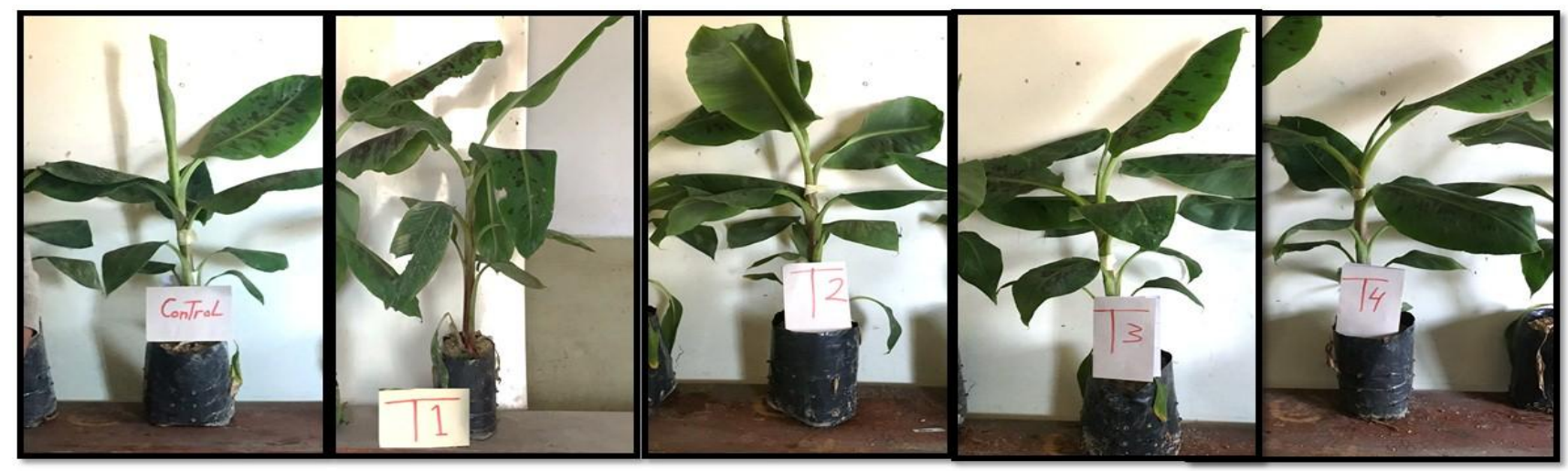

Fig.2 Effect of mycorrhiza inoculation (AMF) on the root system parameters of Banana plantlets in nursery

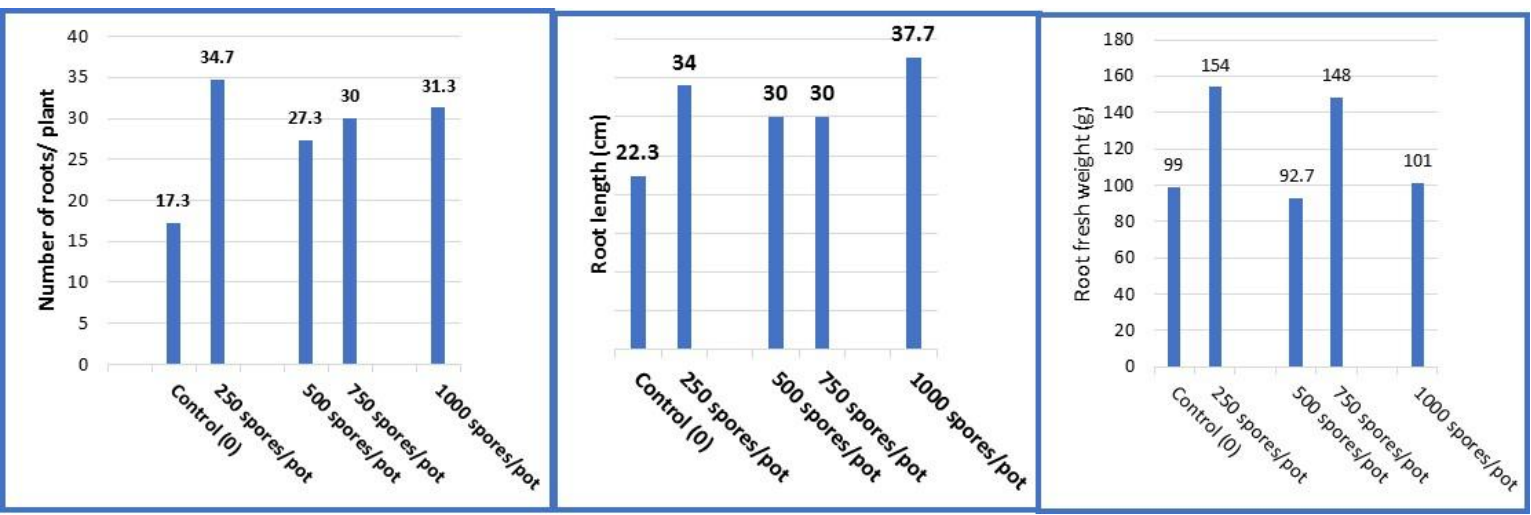

Fig.3 Effect of mycorrhiza inoculation (AMF) on the root system parameters of Banana plantlets in nursery

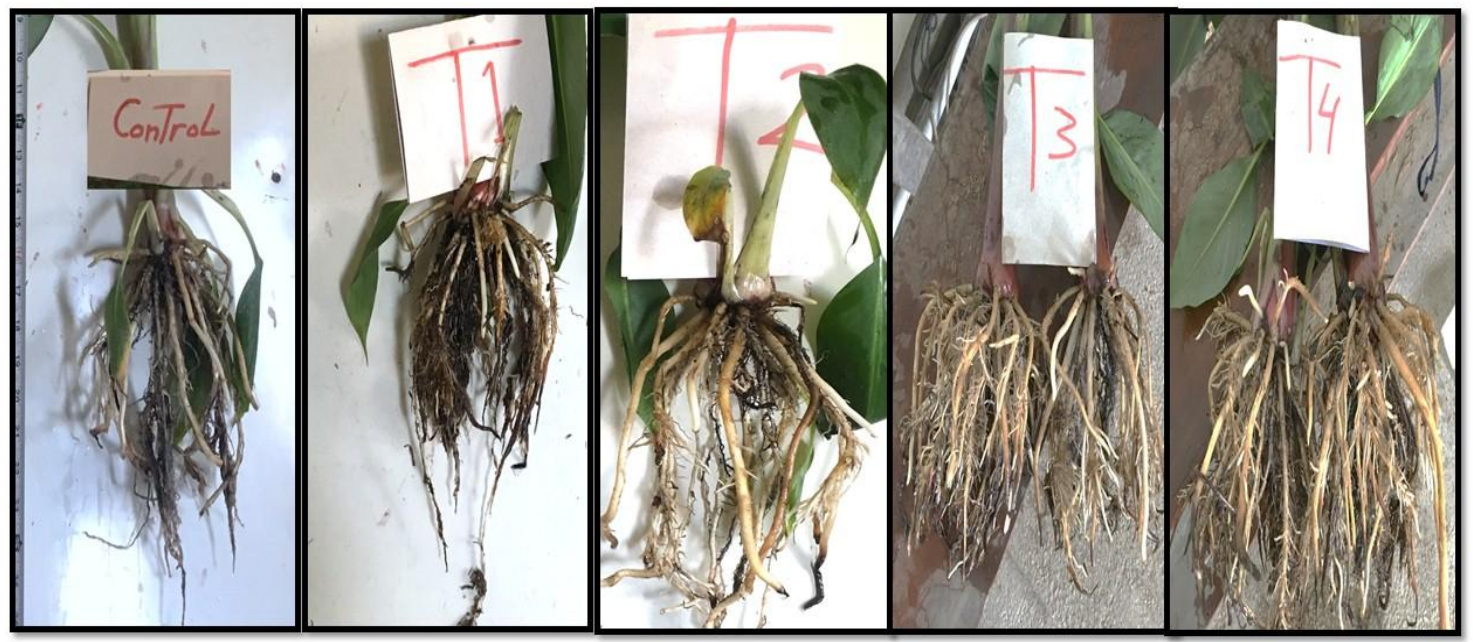


Fig.4 Effect of mycorrhiza inoculation (AMF) on some macroelements content and protein \% of banana plantlets during nursery

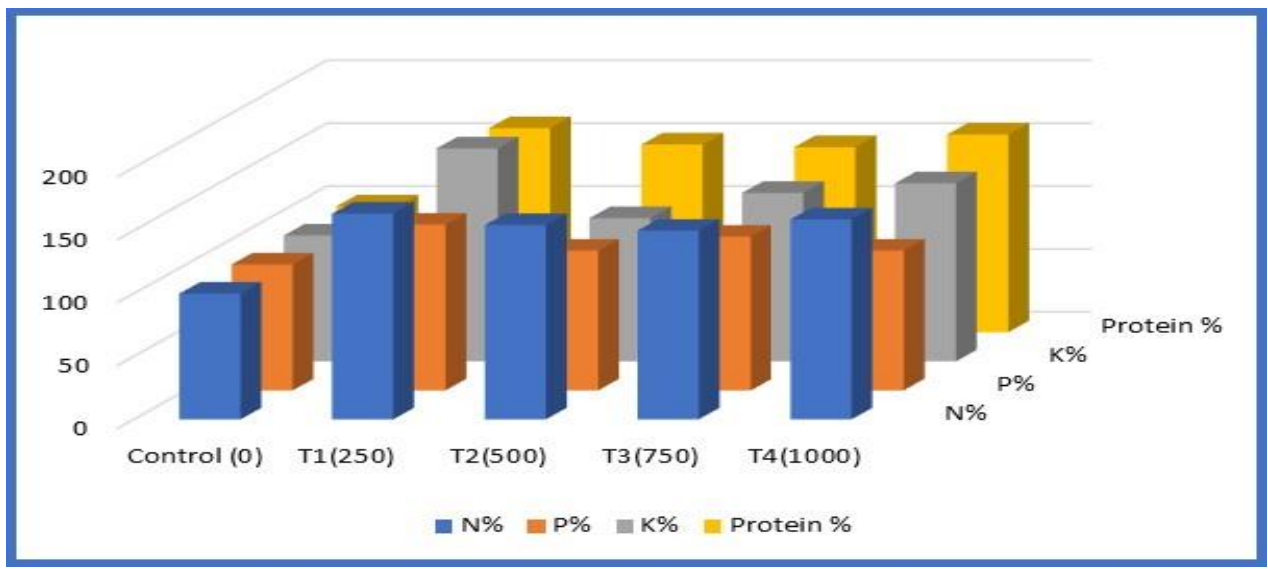

Fig.5 Light microscope photo shows the difference between non-inoculation (A) and inoculation (B) roots

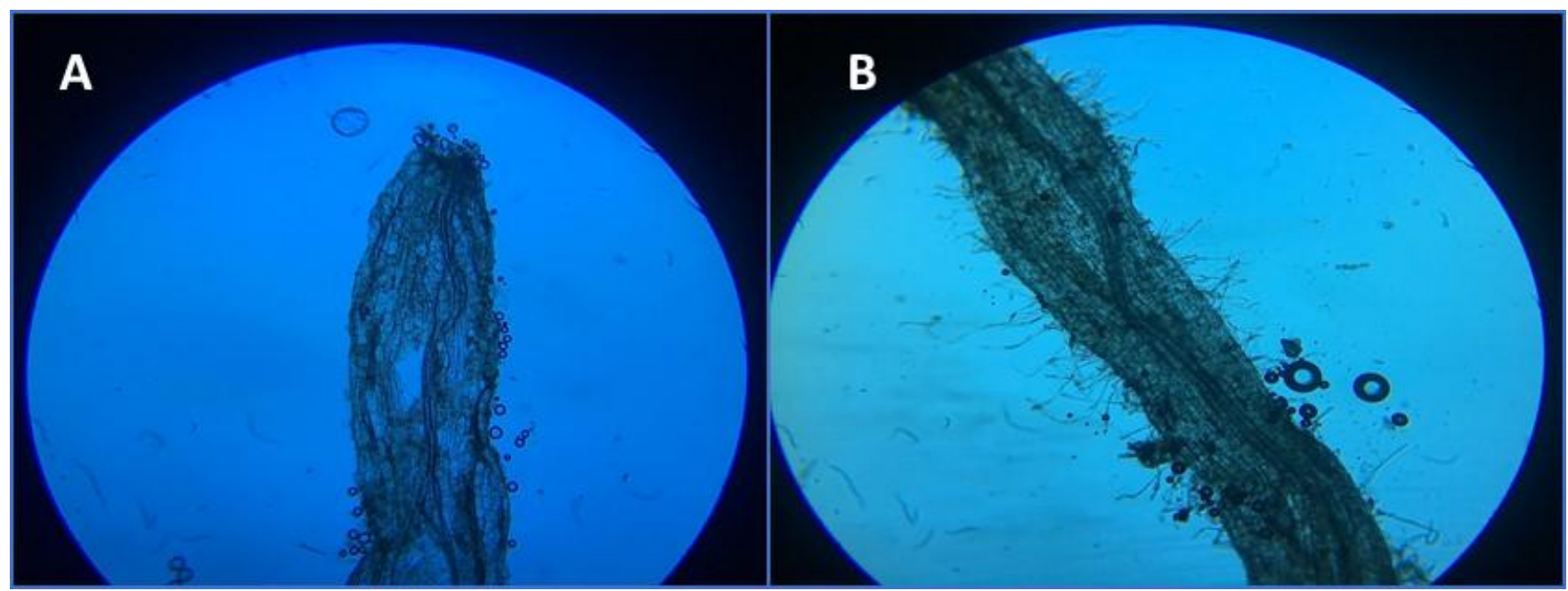

Concerning the root system development as affecting by AMF inoculation, the root system included roots number was ascending to 34.7 roots/plant, which mean $100 \%$ priority compared with non- inoculation plants (control) (17.3 roots/plant). Mycorrhiza inoculation resulted in positive effect on tall of roots, all inoculation treatments gave longer roots than the control (without addition of Mycorrhiza), roots length ranged from 30.0 to $37,7 \mathrm{~cm}$ with superiority percent reached to $69.1 \%$ over the non-inoculation plants (control) (Table 2; Figure 2 and 3). Root weights were enhanced by AMF inoculation, the highest root weight $(154 \mathrm{~g})$ was obtained from T1 (250 spores/pot) with high superior percent $(55.56 \%)$ when compared with noninoculation treatment (control). Indeed, all responses of root parameters were improved by AMF inoculation, these responses may be due to the positive effects of AMF inoculation on nutrition system of plant as well as improved soil environment around roots system. Also, AMF plays important role as symbiotic fungi where it positively affected plant growth parameters. 
Effect of mycorrhiza inoculation (AMF) on some macroelements content and protein \% of banana plantlets during nursery

Concerning plant mineral content, data cleared that nitrogen, phosphor and potassium content significantly increased by treating plants with arbuscular mycorrhiza fungus. Deep observation of the results of each macro element revealed that AMF inoculation treatments increased Nitrogen content compared with control. Superiority percent of Nitrogen content ranged from 50 to $63.6 \%$ over the non-inoculation plants (control). Also, plant content of both $\mathrm{P}$ and $\mathrm{K}$ were significantly increased ascending when plants were treated with various doses of AMF compared with non-inoculation plants (control).

Anyway, the superiority of $\mathrm{P}$ and $\mathrm{K}$ contents of treated plants reached $31.75 \%$ and $69.2 \%$, respectively. These results may refer to the ability of AMF to increase macro-nutrients uptake through improvement of soil quality. On the other hand, inoculation of Mycorrhiza in banana pots media increased the total protein in the shoot system compared with non-inoculation pants. The percent of superiority of treated plants in protein content ranged from 47.14 to $62.14 \%$ over the control treatment as shown in (Table 3 and Figure 4).

\section{Mycorrhiza colonization}

Mycorrhizal colonization was ensured in root system of inoculated plants with various doses compared with control (Figure 5). Colonization level ranged between 40 to $45 \%$ and the low infection level of mycorrhiza possessed high colonization with slight differences when compared with high infection level.

Inoculation banana cultivar Grande Naine with various doses of arbuscular mycorrhiza fungi (AMF) during nursery stage improved vegetative growth parameters, number of leaves, leaf area, plant height, pseudostem length, fresh and dry weight were increased as a result of inoculation with mycorrhiza, vegetative growth of infected plants was superior compared with control (noninoculation). On the other side, mycorrhiza inoculation resulted in positive effect on banana root parameters; number, tall and weight of roots, all inoculation treatments gave higher root parameters than the control (without addition of mycorrhiza). Also, mineral up take, and total protein of banana plants were enhanced as a result of inoculation; especially $\mathrm{N}, \mathrm{P}$ and $\mathrm{K}$ as well as protein.

These results may be due to the symbiotic effect of AMF, where it saves a good soil environment around the root zone of plant and the later supply mycorrhiza with its hormones requirements. Also, mycorrhiza help plants to improve nutrients uptake by in direct or indirect ways. These results supported with those obtained by Rodríguez-Romero et al., (2005), Jaizme-vega et al., (2003, 2004) and Declerck et al., (2002) who reported that arbuscular mycorrhizal fungi increase plant growth parameters and mineral nutrition up take.

On the other hand, results came against reported results of Declerck et al., (1995) who examined the effect of AMF on several banana cultivars and detected different growth promotional effects depending on the banana cultivars, this difference may be attributed to use different strain of mycorrhiza. The inoculation level of AMF ranged between 40 to $45 \%$.

Inoculation banana cultivar Grande Naine with various doses of arbuscular mycorrhiza fungus (AMF) during nursery stage improved vegetative growth parameters, root growth 
parameters, mineral up take and protein. Inoculation with 250spor/pots is recommended because of its superiority. Study the methods for save adequate environment for arbuscular mycorrhiza for keep it live around roots zone is argent issue and help to reduce mineral additions.

\section{References}

Aka-Kacar, Y., Ç. Akpinar, A. Agar, Y. YalcinMendi, S. Serce, İ. Ortas (2010). The effect of mycorrhiza in nutrient uptake and biomass of cherry rootstocks during acclimatization. Romanian Biotechnological Letters, 15(3).

Azcon-Aguilar, C., I.G. Padilla, C.L. Encina, R. Azcon, J.M. Barea (1996). Arbuscular mycorrhizal inoculation enhances plant growth and changes root system morphology in micro propagated Annona cherimola Mill. Agronimie, 10:647-652.

Azcon-Aguilar, C., J.M. Barea (1997). Applying mycorrhiza biotechnology to horticulture: significance and potentials. Sci. Hortic, 68:1-4.

Biermann, B. and R.G. Linderman (1983). Increased geranium growth using pretransplant inoculation with mycorrhizal fungus. J Amer. Soc Hortic Sci., 108:972976.

Brundett, M.S., Y. Piche, R.L. Peterson (1985). A development study of the early stages in vesicular-arbuscular mycorrhizal formation, Can. J. Bot., 63, 184-194

Dolcetsanjuan, R., E. Claveria, A. Camprubi, V.Estaun, C. (1996). Calvet Micropropagation of walnut trees (Juglans regia L.) and response to arbuscular mycorrhizal inoculation. Agronimie, 16:639-645

Estrada-Luana, A.A and F.T. Davies, (2003). Arbuscular mycorrhizal fungi influence water relations, gas exchange, abscisic acid and growth of micro propagated Chile Ancho pepper (Capsicum annuum) plantlets during acclimatization and post acclimatization. J Plant Phys, 160:10731083.

Gaur, A. and Adholeya V. (1999). Mycorrhizal effects on the acclimatization, survival, growth and chlorophyll of micro propagated Syngonium and Draceana inoculated at weaning and hardening stages. Mycorrhiza, 9:215-219.

Jackson, M.L., 1958. Soil chemistry analysis. Prentice-Hall, Englewood Cliffs, USA.

Jaizme-Vega, M.C., A.S. Rodríguez-Romero, M.S. Piñero Guerra (2004). Potential use of rhizobacteria from the Bacillus genus to stimulate the plant growth of micropropagated banana. Fruits, 59, 8390.

Jaizme-Vega, M.C., Rodríguez-Romero A.S., Marín Hermoso S., Declerck S. (2003). Growth of micropropagated bananas colonized by root-organ culture produced arbuscular mycorrhizal fungi entrapped in Ca-alginate beads, Plant Soil, 254, 329335.

Jones J.B., B. Benjamin, H.A. Mills (1991) Plant Analysis Handbook, 1 Methods of Plant Analysis and Interpretation, MicroMacro Publishing, Athens, GA, 213 p.

Kapoor R., D. Sharma, A.K. Bhatagar (2008). Arbuscular mycorrhizae in micro propagation systems and their potential applications. Sci Hortic, 116:227-239.

Koske, R.E. and J.N. Gemma (1989). A modified procedure for staining roots to Detect VAM. Mycol Res 92:486-505

Krishna, H., S.K. Singh, R.R. Sharma, R.N. Khawale, M. Grover, V.B. Patel (2005). Biochemical changes in micro propagated grape (Vitis vinifera L.) plantlets due to arbuscular-mycorrhizal fungi (AMF) inoculation during ex vitro acclimatization. Sci Hort., 106: 554-567.

Lovato, P.E., V. Gianinazzi-Pearson, A. Trouvelot, S. Gianinazzi (1996). The state of art of mycorrhizas and micro propagation. Adv Hortic Sci., 1:46-52

Martins, A., A. Caimiro, M.S. Pais (1997). Influence of mycorrhization on physiological parameters of micro 
propagated Castanea sativa Mill. Plants. Mycorrhiza, 7:161-165.

Monticelli, S., G. Puppi, C. Damian (2000). Effects of in vivo mycorrhization on micro propagated fruit tree rootstocks. Appl Soil Ecol, 15:105-111.

Ortas, I. (2008). Field trials on mycorrhizal inoculation in the Eastern Mediterranean Horticultural Region. In: F. Feldmann, Y. Kapulnik, and J. Baar (eds.). Mycorrhiza works. Hannover, Germany.

Ortas, I. and A. Varma (2007). Field trials of bioinoculants. In: R. Oelmüller and A. Varma (eds). Modern tools and techniques. Springer-Verlag, Germany.

Padilla, I.M.G. and C.L. Encina (2005). Changes in root morphology accompanying mycorrhizal alleviation of phosphorus deficiency in micro propagated Annona cherimola Mill. Plants. Sci Hort., 106:360-369.

Phillips J.M., Hayman D.S. (1970) Improve procedures for cleaning roots and stain parasitic and vesicular-arbuscular fungi for rapid assessment of infection, Trans. Br. Mycol. Soc. 55, 158-161.

Rai, M.K. (2001). Current advances in mycorrhization in micro propagation. In Vitro Cell Develop Biol - Plant, 37:158167.

Rodríguez-Romero, A. S., M. S. Piñero Guerra, M. D. C. Jaizme-Vega (2005). Effect of arbuscular mycorrhizal fungi and rhizobacteria on banana growth and nutrition. Agron. Sustain. Dev., 25 395399.

Rund R.C. (1984). Fertilizers. In: Williams S. (Ed.), Official Methods of Analysis of the
Association of Official Analytic Chemist, 14th ed.: 8-37.

Salamanca, C.P., M.A. Herrera, J.M. Barea (1992). Mycorrhizal inoculation of micro propagated woody legumes used in revegetation programs for decertified Mediterranean Ecosystems. Agronomie, 12:869-872.

SAS Institute, 2002. SAS ${ }^{\circledR}$ User's guide: Statistics. Version 9.0. SAS Institute, Cary, North Carolina, USA.

Srinath, J., D.J.Bagyaraj, B.N. Satyanarayana (2003). Enhanced growth and nutrition of micropropagated Ficus benjamina to Glomus mosseae co-inoculated with Trichoderma harzianum and Bacillus coagulans. World J Microbiol Biotechnol, 19: 69-72.

Steel, G.D. and J.H. Torrie (1980). Principles and procedures of statistics, Mc Grow Hill Boot-Col. New York.

Taylor, J. and A.L. Harrier (2000). A comparison of nine species of arbuscular mycorrhizal fungi on the development and nutrition of micro propagated Rubus idaeus L. cv. Glen Prosen (Red Raspberry). Plant Soil, 225:53-61.

Taylor, J. and A.L. Harrier (2001). A comparison of development and mineral nutrition of micro propagated Fragaria $\times$ ananassa cv. Elvira (strawberry) when colonised by nine species of arbuscular mycorrhizal fungi. Appl Soil Ecol, 18:205-215.

Yano-Melo, A.M., L.C. Maia, JR. O.J. Saggin, J.M. Lima-Filho, N.F. Melo (1999). Effect of arbuscular mycorrhizal fungi on the acclimatization of micro propagated banana plantlets. Mycorrhiza, 9: 119-123.

\section{How to cite this article:}

Emara, H.A., A. Nower, E. Hmza, M. Saad and El Shaib, F. 2018. Role of Mycorrhiza as Biofertilization of Banana Grand Naine on Nursery Stage. Int.J.Curr.Microbiol.App.Sci. 7(10): 805-814. doi: https://doi.org/10.20546/ijcmas.2018.710.089 